\title{
Nasal-type extranodal NK/T-cell lymphoma: a diagnostic challenge
}

\author{
Rita Gama (1) , Manuel Sousa, Fernanda Castro, Artur Condé
}

Otorhinolaryngology and Head and Neck Surgery Department, Centro Hospitalar de Vila Nova de Gaia, Porto, Portugal

\section{Correspondence to Dr Rita Gama; ritarocha@campus.ul.pt}

Accepted 9 January 2021

\section{DESCRIPTION}

A 72-year-old man presented to the emergency department with a 3-week history of fatigue, weight loss, night sweats, fever and severe nasal obstruction with nasal discharge. Being possible symptoms of COVID-19 infection, its presence led to the required exclusion of the disease, so he underwent a SARS-CoV-2 RT-PCR test, which revealed to be negative. He was discharged with paracetamol $1 \mathrm{~g}$ every 8 hours and nasal irrigation with saline solution for a common cold.

$\mathrm{He}$ returned to the emergency department 3 days later, reporting the emergence of skin lesions on both legs, which were rapidly evolving in size and extent. On examination by an otolaryngologist, a granulomatous lesion with irregular mucosa and oedema on the anterior portion of the left nasal cavity was identified (figure $1 \mathrm{~A}$ ). $\mathrm{He}$ was also presented multiple firm and dark purple patches with some subcutaneous nodules on both legs (figure $1 \mathrm{~B}$ ), which were painless on palpation, and had a vasculitic appearance. He had no nasal, orbital or other facial deformities.

Laboratory studies revealed a white cell count of $15 \times 10^{9} / \mathrm{L}^{3}$, and a $\mathrm{C}$ reactive protein of $15.33 \mathrm{mg} /$ $\mathrm{dL}$, with no other significant findings.

CT scan images revealed a neoformative lesion occupying the anterior portion of the left nasal cavity with $1 \times 1.4 \mathrm{~cm}$, showing heterogeneous contrast uptake, and conditioning right septum deviation and total obliteration of the anterior left nasal cavity (figure 2).

Two biopsies were performed: one on the left nasal lesion and another on the skin lesions. The histology examination revealed the presence of heterogeneous size cells, with irregular nucleus and sparse cytoplasm, with multiple mitotic and apoptotic figures, as well as mild angiodestruction. These features were compatible with the diagnosis of lymphoma, and the immunohistochemistry analysis made the diagnosis of a primary extranodal natural killer (NK)/T-cell lymphoma (ENNKTL), nasal type, showing the typical immunophenotype of CD56+, CD2+ and cytoplasmic CD3+. The proliferation index of Ki67 was 10\%. Chromogenic in situ hybridization (CISH) staining for Epstein-Barr virus (EBV)-encoded RNA transcript was positive.

The patient started chemoradiation therapy, but unfortunately died after 2 weeks.

ENNKTL, nasal type, also known as lethal midline granuloma, is an Epstein-Barr virusassociated lymphoma, and represents about $0.44 \%$ of the extranodal sinonasal lymphomas. ${ }^{12}$

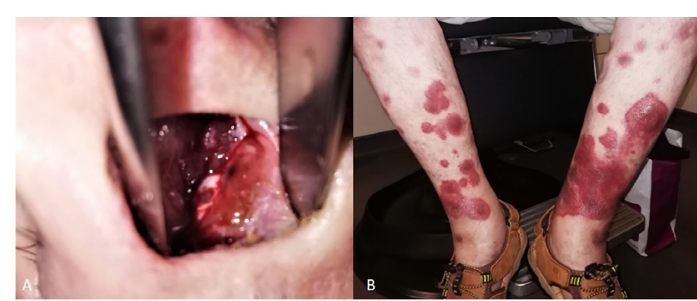

Figure 1 (A) Anterior rhinoscopy showing the nasal lesion on the left nasal cavity. (B) Skin lesions on both legs.

The nose is the most common initial involved site, and can manifest as an intranasal lesion conditioning obstructive symptoms, with bleeding and purulent nasal discharge. ${ }^{3}$ Commonly it manifests with unspecific symptoms of rhinitis or sinusitis, making a malignant diagnosis difficult to suspect.

The skin is the primary site where ENNKTL spreads to, being the emergence of firm, multiple and dark purple subcutaneous nodules the most frequent cutaneous finding, as in the presented case. ${ }^{4}$ This is probably due to its angiocentric and angioinvasive nature, which is responsible for the blood vessel wall destruction.

ENNKTL is a rare disease, with a recognised poor prognosis, due to its invasive and agressive behaviour, as well as its lack of response to chemotherapy and radiotherapy regimens. ${ }^{5-7}$

As the primary manifestations of COVID-19 consist of respiratory symptoms, ${ }^{8} 9$ it is understandable that the case described has first been approached as a highly suspect case. The refractory behaviour of its symptoms to the implemented treatments raised an alert.

In this challenging time, it can become difficult to divert attention from a possible COVID-19 diagnosis in the presence of a typical clinic, but trying to decrease the misdiagnosis of other treatable entities is of paramount importance.

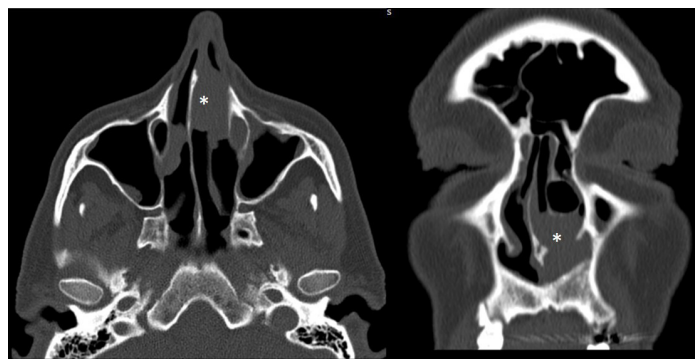

Figure 2 CT images revealing a space-occupying lesion on the anterior portion of the left nasal cavity (*). 


\section{Learning points}

- The extranodal natural killer/T-cell lymphoma, nasal type, commonly manifests with unspecific symptoms of rhinitis or sinusitis, making a malignant diagnosis difficult to suspect.

- We aim to raise the alert between Ear,Nose and Throat (ENT) residents and family doctors to the possibility of such an unsuspected nasal and systemic clinic could represent this very uncommon malignant.

- One of the most important and dangerous consequences of the SARS-CoV-2 pandemic could be the higher missed screening and diagnosis of other diseases, as both the clinicians and the patients themselves are focused on suspected or confirmed COVID-19.

We aim to describe a case of ENNKTL with both nasal and cutaneous features, so that an alert can be raised between physicians of all specialties, and so the inclusion of this entity in the differential diagnosis of such a combination of manifestations can be made.

Contributors RG wrote the paper and collected the data. MS corrected the paper; diagnosis. CF and AC revised and corrected the paper.

Funding The authors have not declared a specific grant for this research from any funding agency in the public, commercial or not-for-profit sectors.
Competing interests None declared.

Patient consent for publication Obtained.

Provenance and peer review Not commissioned; externally peer reviewed.

\section{ORCID iD}

Rita Gama http://orcid.org/0000-0003-0198-7321

\section{REFERENCES}

1 Peh SC. Host ethnicity influences non-Hodgkin's lymphoma subtype frequency and Epstein-Barr virus association rate: the experience of a multi-ethnic patient population in Malaysia. Histopathology 2001;38:458-65.

2 Tai Y-C, Kim L-H, Peh S-C. High frequency of EBV association and 30-bp deletion in the LMP-1 gene in CD56 lymphomas of the upper aerodigestive tract. Pathol Int 2004;54:158-66.

3 Sheahan P, Donnelly M, O'Reilly S, et al. T/Nk cell non-Hodgkin's lymphoma of the sinonasal tract. J Laryngol Otol 2001;115:1032-5.

4 Chan JK, Sin VC, Wong KF, et al. Nonnasal lymphoma expressing the natural killer cell marker CD56: a clinicopathologic study of 49 cases of an uncommon aggressive neoplasm. Blood 1997;89:4501-13.

5 Cheung MMC, Chan JKC, Wong K-F. Natural killer cell neoplasms: a distinctive group of highly aggressive lymphomas/leukemias. Semin Hemato/ 2003;40:221-32.

6 Chim C-S, Ma S-Y, Au W-Y, et al. Primary nasal natural killer cell lymphoma: long-term treatment outcome and relationship with the International prognostic index. Blood 2004:103:216-21

7 Lee J, Suh C, Park YH, et al. Extranodal natural killer T-cell lymphoma, nasal-type: a prognostic model from a retrospective multicenter study. J Clin Oncol 2006;24:612-8.

8 Wang D, Hu B, Hu C, et al. Clinical characteristics of 138 hospitalized patients with 2019 novel coronavirus-infected pneumonia in Wuhan, China. JAMA 2020;323:1061-9.

9 Zhou P, Yang X-L, Wang X-G, et al. A pneumonia outbreak associated with a new coronavirus of probable bat origin. Nature 2020;579:270-3.

Copyright 2021 BMJ Publishing Group. All rights reserved. For permission to reuse any of this content visit

https://www.bmj.com/company/products-services/rights-and-licensing/permissions/

BMJ Case Report Fellows may re-use this article for personal use and teaching without any further permission.

Become a Fellow of BMJ Case Reports today and you can:

- Submit as many cases as you like

- Enjoy fast sympathetic peer review and rapid publication of accepted articles

- Access all the published articles

Re-use any of the published material for personal use and teaching without further permission

Customer Service

If you have any further queries about your subscription, please contact our customer services team on +44 (0) 2071111105 or via email at support@bmj.com.

Visit casereports.bmj.com for more articles like this and to become a Fellow 